\title{
ARCHAIC BALEEN WHALES FROM THE OLIGOCENE-EARLIEST MIOCENE OF THE SOUTHWEST PACIFIC
}

\author{
ICHISHIMA*, Hiroto; FORDYCE, R. Ewan; Dept. of Geology, University of \\ Otago, P.O. Box 56, Dunedin, New Zealand
}

Archaic baleen whales from New Zealand include some of the earliest (Oligocene) records of toothless Mysticeti. Four named species are placed in the widely cited genus Mauicetus, of which only the type-species Mauicetus parki (based on a partial skull; Oligocene-Miocene boundary) clearly represents the genus. Recentlydiscovered later Oligocene and earliest Miocene baleen whales from the Waitaki Valley region include species apparently close to Mauicetus parki. Where preserved, the rostrum is toothless and long, and probably carried baleen. Mandibles lack a bony symphysis. The frontals are only gently depressed, and the parietals are long. In the basicranium, earbones show presumed derived features shared with living balaenopterids.

Mauicetus is usually referred to the family Cetotheriidae, a group widely regarded as ancestral to living baleen whales. As currently diagnosed, however, this family is paraphyletic and probably polyphyletic. The Cetotheriidae takes its identity ultimately from the enigmatic Cetotherium rathkii (late Miocene, Europe). Mauicetus does not clearly share synapomorphies with $\underline{\mathrm{C}}$. rathkii, and thus probably does not belong in the Cetotheriidae.

Mauicetus (sensu stricto) may be closer to balaenopterids than to right whales and pygmy right whales. Mauicetus-like taxa thus may push the origins of the balaenopterid clade back into the Oligocene, rather longer than predicted by some molecular studies. Further, Mauicetus-like fossils show no evidence of structural similarity with sperm whales, a living group of toothed whales which, according to some molecular studies, are a sister taxon to balaenopterids. 